\title{
Conversion of Food Wastes and by-Products in to Value Added Products
}

\author{
Mehmet Koç* \\ Department of Food Engineering, Adnan Menderes University, Turkey
}

Submission: March 03, 2017; Published: March 21, 2017

"Corresponding author: Mehmet Koç, Department of Food Engineering, Faculty of Engineering, Adnan Menderes University, Turkey, Tel: +90-256-213-7503; Fax: +90-256-213-6686; Email: mehmetkoc@adu.edu.tr

\begin{abstract}
Food industry generated voluminous and serious amounts of food wastes and by-products due to rapid urbanization, industrialization and population growth. Conversion of these food wastes and by-products into value added products is very important for not only economic aspect but also social and environmental sides. 3R's concept, i.e., Reduce, Reuse, and Recycle should be follow to overcome food waste issue in food industry. In this review, thermal, chemical and biological conversion methods were explained in detail to recovery food wastes and by-products.
\end{abstract}

Keywords: Food waste; Food by-product; Extraction; Hydrothermal carbonization; Anaerobic digestion

\section{Introduction}

Food and beverage production is an industry with the main raw materials generally obtained from plant and animal sources and the industry has always aimed to convert these raw materials to a value added products. During this conversion processes, voluminous and serious amounts of food wastes and by-products are generated. Unfortunately, one-third of the global food production is wasted worldwide every year [1]. Vandermeersch et al. [2] explained the effects of such a high amount of food waste generation considering there different approaches, for instance crop losses during harvest or storage (economic), hunger in low-income countries (social), and the deprivation of natural resources without accomplishing its final purpose (environmental). FAO [3] reported seriously worrisome findings about food wastes, for example every year, consumers in rich countries waste almost as much food (222 million tonnes) as the entire net food production of sub-Saharan Africa (230 million tonnes). Memon [4], Sakai et al. [5] suggested 3R's concept, i.e., Reduce, Reuse, and Recycle to overcome food waste issue throughout the world.

That's why waste management systems also begins with waste minimization. Riemer \& Kristoffersen [6] suggested four ways to achieve perfect waste minimization in the industry as follow;

A. Waste prevention with using more efficient production technologies

B. Internal recycling of production waste
C. Source-oriented improvement of waste quality

D. Reuse of products. A number of by-products are also somewhat discarded in food industry without any process although they can be used to produce valuable products. In this review, the methods that have been generally preferred to convert by products to value added products are investigated.

\section{Thermal Conversion}

The thermal conversion of food by-products or waste especially solid form bases on production of fuel and chemicals that are generally used to operate steam turbines for energy production or for heat exchangers used to heat up process streams in industry [7]. The basic thermal conversion processes are pyrolysis and hydrothermal carbonization. Food wastes are burned at temperatures less than $450^{\circ} \mathrm{C}$ and become gaseous at temperatures above $800{ }^{\circ} \mathrm{C}$ during pyrolysis. Although pyrolysis is a very promising method to utilize food wastes, so far no pyrolysis processes have been developed solely for food processing wastes [8]. Hydrothermal carbonization is a wet process that converts food wastes to a valuable, energyrich resource under autogenous pressures and relatively low temperature $\left(180-350{ }^{\circ} \mathrm{C}\right.$ ) compared to pyrolysis [9]. Parshetti et al. [10] used hydrothermal carbonization method to prepare hydrochars from urban food wastes for removal of textile dyes from contaminated water. 


\section{Chemical Conversion}

In food processing industry, hydrolysis and oxidation reactions are mostly used as chemical conversion methods for food wastes and by-products. Berdanier [11] reported that food wastes or byproducts rich in starch and protein content can be treated with appropriate acids or enzymes to produce valuable products such as maltose, glucose and amino acids. Solvent extraction is also preferred to extract valuable organic acids, vitamins, antioxidants, phenolic compounds, coloring agents from food wastes and byproducts. Amado et al. [12] tried to extract antioxidant from potato peel waste with ethanol. They investigated the effect of extraction process conditions in terms of temperature, time and ethanol concentration on antioxidant extraction from potato peel. Goula \& Lazarides [13] reported how valorized the olive mill and pomegranate waste. They suggested different approaches for complete utilization of pomegranate seeds and peels based on ultrasound-assisted extraction of oil and phenolics from seeds and peels and conversion of olive mill waste into live paste spread or olive powder (to be included in food formulations) and encapsulated polyphenols.

Valuable parts of food wastes and by-products can be also extracted by green extraction techniques where water is mostly preferred as extraction medium instead of organic solventextraction. Barba et al. [14] reviewed in detail alternative extraction methods such as pulsed electric fields, high voltage electrical discharges, pulsed ohmic heating, ultrasounds, microwave-assisted extractions, sub- and supercritical fluid extractions, as well as pressurized liquid extraction for the recovery of antioxidant bioactive compounds from winery wastes and by-products. Zungur et al. [15] was also used water to extract melon seed milk from melon seeds that generally referred as waste.

\section{Biological Conversion}

Energy and bioactive compounds recovery from food wastes and by-products through biological treatment is currently gaining increased interest throughout the world. Food waste has a high content of moisture and organic matter, and thus is an ideal substrate for anaerobic digestion. The process of anaerobic digestion consists of four steps: hydrolysis, acidogenesis, acetogenesis, and methanogenesis [16]. $\mathrm{pH}$, temperature, and organic loading rate have an effect on the acidogenesis of food waste [17]. Chandrasekaran [8] reported that anaerobic digestion created biogas, primarily made of methane and carbon dioxide, which could be used as a source of energy similar to natural gas. Besides anaerobic digestion, composting of food wastes and by-products is also one of biological conversion method. Composting is a biological process in which organic materials are broken down and nutrients and minerals are released.

\section{Conclusion}

Food wastes are one of worrisome issue for people and environment. That's why valorization of food wastes and by-products is very important due to social, economic and environmental reasons. Food wastes and by-products can be converting into valuable products through thermal, chemical and biological methods. The appropriate conversion method is selected with respect to composition of food wastes and by-products and the aim of recovery process.

\section{References}

1. Gustavsson J, Cederberg C, Sonesson R, van Otterdijk R, Meybeck A (2011) Global food losses and food wastes: extent, cause and prevention. Interpack 2011 FAO, Dusseldorf, Germany, pp. 1-37.

2. Vandermeersch T, Alvarenga RAF, Ragaert P, Dewulf J (2014) Environmental sustainability assessment of food waste valorization options. Resour Conserv Recy 87: 57-64.

3. http://www.fao.org/save-food/resources/keyfindings/en/

4. Memon M A (2010) Integrated solid waste management based on the 3R approach. J Mater Cycles Waste 12(1): 30-40.

5. Sakai SI, Yoshida H, Hirai Y, Asari M, Takigami H, et al. (2011) International comparative study of $3 \mathrm{R}$ and waste management policy developments J Mater Cycles Waste 13(2): 86-102.

6. Riemer J, Kristoffersen M (1999) Information on waste management practices. A proposed electronic framework. European Environmental Agency, Copenhagen, Denmark.

7. Autret E, Berthier F, Luszezanec A, Nicolas F (2007) Incineration of municipal and assimilated wastes in France: Assessment of latest energy and material recovery performances. J Hazard Mater 139(3): 569-574.

8. Chandrasekaran M (2012) Valorization of food processing by-products. Boca Raton, CRC Press, USA, pp. 836.

9. Pham TPT, Kaushik R, Parshetti GK, Mahmood R, Balasubramanian R (2015) Food waste-to-energy conversion technologies: Current status and future directions. Waste Manage 38: 399-408.

10. Parshetti GK, Chowdhury S, Balasubramanian R (2014) Hydrothermal conversion of urban food waste to chars for removal of textile dyes from contaminated waters. Bioresource Technol 161: 310-319.

11. Berdanier CD (1998) CRC Desk Reference for Nutrition. Boca Raton, CRC Press, USA.

12. Amado IR, Franco D, Sánchez M, Zapata C, Vázquez JA (2014) Optimisation of antioxidant extraction from Solanum tuberosum potato peel waste by surface response methodology. Food Chem 165: 290-299.

13. Goula AM, Lazarides HN (2015) Integrated processes can turn industrial food waste into valuable food by-products and/or ingredients: The cases of olive mill and pomegranate wastes. Journal of Food Engineering 167: 45-50.

14. Barba FJ, Zhu Z, Koubaa M, Santana AS, Orlien V (2016) Green alternative methods for the extraction of antioxidant bioactive compounds from winery wastes and by-products: A review. Trends in Food Science \& Technology 49: 96-109.

15. Zungur BA, Tomruk D, Koç M, Ertekin KF (2016) Spray dried melon seed milk powder: physical, rheological and sensory properties. J Food Sci Technol 53(5): 2396-2404.

16. De La Rubia MA, Raposo F, Rincón B, Borja R (2009) Evaluation of the hydrolytic-acidogenic step of a two-stage mesophilic anaerobic digestion process of sunflower oil cake. Bioresource Technol 100(18): 4133-4138.

17. Jiang J, Zhang Y, Li K, Wang Q, Gong C, et al. (2013) Volatile fatty acids production from food waste: effects of $\mathrm{pH}$, temperature, and organic loading rate. Bioresource Technol 143: 525-530. 
This work is licensed under Creative Commons Attribution 4.0 License

DOI: $10.19080 /$ ARTOAJ.2017.04.555652

\section{Your next submission with Juniper Publishers will reach you the below assets}

- Quality Editorial service

- Swift Peer Review

- Reprints availability

- E-prints Service

- Manuscript Podcast for convenient understanding

- Global attainment for your research

- Manuscript accessibility in different formats ( Pdf, E-pub, Full Text, Audio)

- Unceasing customer service

Track the below URL for one-step submission https://juniperpublishers.com/online-submission.php 